\title{
Protection of the Polish written and printed heritage - National Library Resource
}

\author{
Agnieszka Fluda-Krokos
}

Agnieszka Fluda-Krokos, PhD

Pedagogical University of Cracow

Institute of Information Sciences

ul. Podchorażych 2

30-084 Cracow

Poland

e-mail: agnieszka.fluda-krokos@up.krakow.pl,a.fluda_krokos@interia.pl

ORCID: 0000-0002-0934-8965

Muzeológia a kultúrne dedičstvo, 2020, 8:3:111-128

DOI: $10.46284 / \mathrm{mkd} .2020 .8 .3 .6$

Protection of the Polish written and printed heritage - National Library Resource

Written and printed works are one of the most important cultural achievements of every country and nation. This often priceless heritage is protected, among other things, by libraries which are responsible for collecting, preparing, storing, protecting and sharing their collections. The article focuses on one form of protection of these resources - the Polish National Library Resource (NLR), which has a legal basis and gives examples of good practice. The analysis presented in this paper covers the normative Acts that cover only those collections which are unique and exceptionally valuable for Polish culture. It was found that perception of these special collections has changed and that nowadays there are only a small number of libraries that take part in the NLR programme.

Keywords: heritage, printing, writing, protection, Poland

\section{Introduction}

Libraries are institutions responsible for collecting, preparing, storing, protecting and sharing library resources, which may be included under the category of movable cultural heritage. According to Section 3.1 of Poland's Act of 27 June 1997 on the libraries "Libraries and their collections are part of the national treasure and are used to preserve national heritage". 1

According to the latest data, based on reports submitted by individual libraries $(\mathrm{K}-03-\mathrm{Li}$ braries Report Form ${ }^{2}$ and given by Statistics Poland, in Poland in 2018 there were 9,406 libraries. ${ }^{3}$

The aim of this article is to present the legal position and facts about a small number of Polish library collections, known as the National Library Resource (hereinafter: NLR), which was defined in Section 6 of the Act of 27 June 1997 on the libraries: "Library collections that have unique value and meaning for the national heritage are, in full or in part, a National Library Resource." The same section also emphasizes that the NLR is given special protection (Section 6.2) and indicates a further legislative framework: that the Minister of Art and Culture, in

\footnotetext{
${ }^{1}$ Act of 27 June 1997 on the Libraries [Ustawa z dnia 27 czerwca 1997 r. o bibliotekach], Journal of Laws 1997, No. 85, item 539, accessed 7 January 2019, http://prawo.sejm.gov.pl/isap.nsf/download.xsp/WDU19970850539/O/ D19970539.pdf.

${ }^{2}$ K-03 - Libraries Report [Sprawozdanie bibliotek. K-03], accessed 7 January 2019, http://form.stat.gov.pl/formularze/2018/passive/K-03.pdf.

${ }^{3}$ Culture in 2016 [Kultura w 2016 r.], Warsaw: Główny Urząd Statystyczny 2017, p. 79.

4 Act of 27 June 1997 on Libraries.
} 
agreement with the competent ministers, is to establish, by regulation, a list of libraries whose collections belong to the National Library Resource, define the structure of the resource and set the rules and the scope of its special protection ${ }^{5}$ (section 6.3). Such regulations were published in 1998, 2009, 2012, 2016 and 2017.

\section{Libraries in Poland}

In Poland there is an extensive library network which is composed of leading facilities of various types: public, scientific, pedagogical, educational and professional. The main acts governing the rules under which they function are the Act of 27 June 1997 on the libraries ${ }^{6}$ and the Minister of Culture and National Heritage Regulation of 29 October 2008 on the way to keep records of library resources. ${ }^{7}$ Moreover, every type of library also has its own regulations which specifically define how it should function. In the case of public libraries, the relevant legislation is the Act of 25 October 1991 on organizing and running cultural activity; ${ }^{8}$ in the case of scientific libraries the pertinent document is the Minister of Culture and National Heritage Regulation of 12 December 2017 amending regulation on the method and procedure for the inclusion of a library among certain scientific libraries and setting their list. ${ }^{9}$ In the case of pedagogical libraries, the pertinent legislation is the Minister of National Education Regulation of 28 February 2013 on the detailed rules of functioning of the public pedagogical libraries ${ }^{10}$ and the Minister of National Education and Sport Regulation of 29 April 2003 on the framework statute of the public pedagogical library. ${ }^{11}$ Internal documents such as statutes, rules and regulations govern the activity of facilities are.

\footnotetext{
${ }^{5}$ Ibid.

${ }^{6}$ Ibid.

${ }^{7}$ Minister of Culture and National Heritage Regulation of 29 October 2008 on the way of keeping records of the library resources [Rozporzadzenie Ministra Kultury i Džiedzictwa Narodowego z dnia 29 października 2008 r. w sprawie sposobu ewidencji materiatón bibliotecznych], Journal of Laws 2008, No. 205, item 1238, accessed 2 January 2019, http://prawo.sejm.gov.pl/ isap.nsf/DocDetails.xsp?id=WDU20082051283.

${ }^{8}$ The Act of 25 October 1991 on organizing and running cultural activity [Ustawa z. dnia 25 paźdżiernika 1991 r. o organizowaniu i prowadženiu działalności kulturalnej], Journal of Laws 1991, No. 114, item 493, accessed 7 January 2019, http:/ / prawo. sejm.gov.pl/isap.nsf/DocDetails.xsp?id=wdu19911140493.

${ }^{9}$ Minister of Culture and National Heritage Regulation of 12 December 2017 amending regulation on the method and procedure of including libraries in certain scientific libraries, and setting their list [Rozporzadzenie Ministra Kultury i Dziedzictwa Narodowego z. dnia 12 grudnia 2017 r. zmieniajace rozporzqdzenie w sprawie sposobu i trybu zaliczania bibliotek do niektórych bibliotek naukowych oraz ustalenia ich wykazu], Journal of Laws 2017, item 2427, accessed 7 January 2019, http:/ /prawo.sejm.gov.pl/isap. nsf/DocDetails.xsp?id=WDU20170002427.

${ }^{10}$ Minister of National Education Regulation of 28 February 2013 on the detailed rules of functioning of the public pedagogical libraries [Rozporzqdzenie Ministra Edukacïi Narodowej z. dnia 28 lutego 2013 r. w sprawie szczegótonych zasad dziatania publicznych bibliotek pedagogicznych], Journal of Laws 2013, item 369, accessed 7 January 2019, http://prawo.sejm.gov.pl/ isap.nsf/DocDetails.xsp?id=WDU20130000369.

${ }^{11}$ Minister of National Education and Sport Regulation of 29 April 2003 on the framework statute of the public pedagogical library [Rozporzqdzenie Ministra Edukacji Narodowej i Sportu z dnia 29 kwietnia 2003 r. w sprawie ramowego statutu publicznej biblioteki pedagogicznej], Journal of Laws 2003, No. 89, item 825, accessed 7 January 2019, http://prawo.sejm.gov.pl/isap.nsf/ DocDetails.xsp?id=WDU20030890825.
} 
Year by year the number of libraries in Poland is decreasing. For comparison, data from nine different years were chosen ${ }^{12}-1998,{ }^{13} 2009,{ }^{14} 2012,{ }^{15} 2013,{ }^{16} 2014,{ }^{17} 2015,{ }^{18} 2016,{ }^{19} 2017^{20}$ and $2018 . .^{21}$

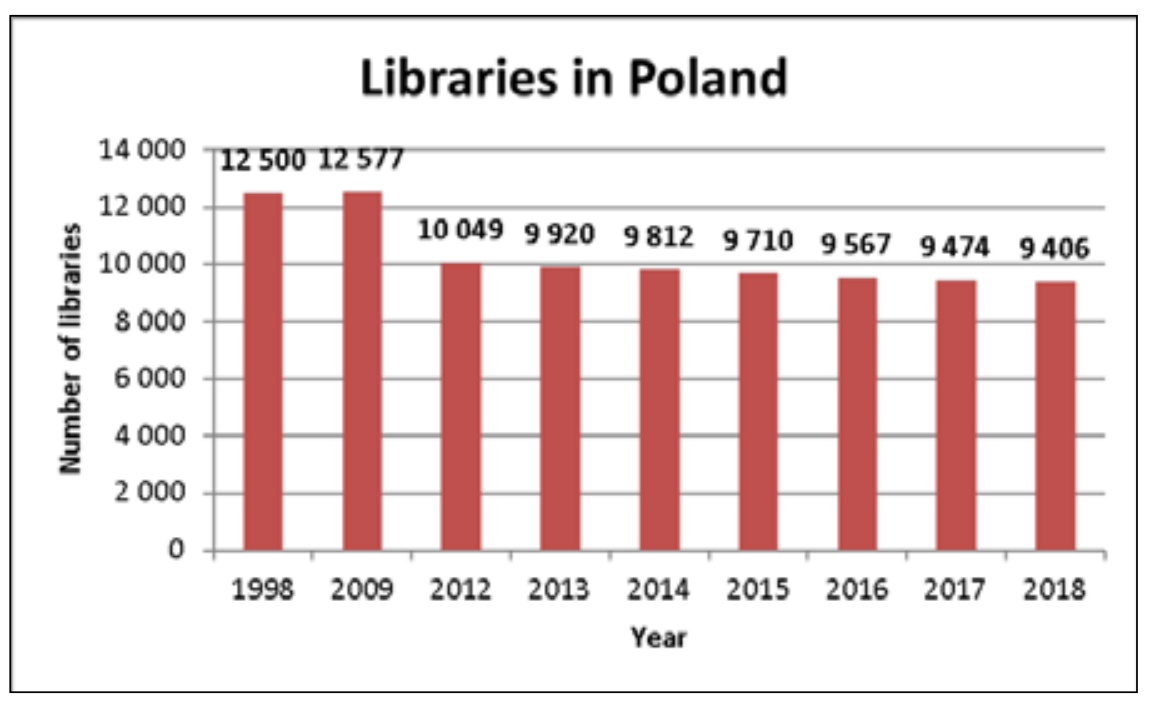

Figure 1: Number of libraries in Poland. [Source: own work]

During 21 years since the first regulation on the NLR was published, 3,094 libraries have disappeared from the Polish map, representing a decrease of around $25 \%$. While investigating regulations from the years 1998, 2009, 2012 and 2016, we can successively compare the number of facilities with the initial number of 12,500 in 1998). In 2009 there were 77 more facilities, in 2012 there were 2,451 fewer and in 2016 there were 2,933 fewer than in 1998. Considering more recent years, in 2017 there were 3,026 fewer and in 2018 there were 3,094 fewer than in 1998.

\section{National Library Resource}

The term NLR was used for the first time in 1977 during a meeting of the management of the National Library and Jagiellonian Library (16 January). In the course of the meeting there were discussions about planning for the specialization of library resources concerning Polish national culture. After the Ossoliński National Institute joined the project, a document entitled National library resource. General programme and organisation assumptions was prepared. It was

\footnotetext{
${ }^{12}$ In the years 1998, 2009, 2012, 2016 regulations on the National Library Resource were published. The latest one, from 2017, presents no data about the number of libraries.

${ }^{13}$ Library network in Poland, library collections and reading in the nineties [Sieć bibliotek $w$ Polsce, zbiory biblioteczne oraz. caytelnictwo w latach dziewię́́dżiesiatych], accessed 7 January 2019, http://biurose.sejm.gov.pl/teksty_pdf_01/i-797.pdf, p. 2.

${ }^{14}$ Culture in 2009 [Kultura w 2009 r.], Warsaw: Główny Urząd Statystyczny, 2010, p. 56, 84.

${ }^{15}$ Culture in 2012 [Kultura w 2012 r.], Warsaw: Główny Urząd Statystyczny, 2013, p. 69.

${ }^{16}$ Ibid., p. 68.

${ }^{17}$ Ibid., p. 71.

${ }^{18}$ Ibid., p. 74.

${ }^{19}$ Culture in 2016, p. 79.

${ }^{20}$ Culture in 2017 [Kultura w 2017 r.], Warsaw: Główny Urząd Statystyczny, 2018, p. 38.

${ }^{21}$ Culture in 2018 [Kultura w 2018 r.], Warsaw: Główny Urząd Statystyczny, 2019, p. 40.
} 
approved by the Ministry of Art and Culture on 21 October $1977 . .^{22}$ The NLR was then given the following definition and objectives:

the aim of the National Library Resource (NLR) is to collect, comprehensively register, prepare information about and enable access to documents, created by Poles and concerning Poland, which are the basic source of information about the intellectual output of the Poles, the political history of the nation, the history of the national culture and all its domains of activity, the history of raising national awareness [and] the history of Polish contribution to world civilisation. ${ }^{23}$

As the main reason for setting up the NLR, Leon Marszałek points to history and mentions the loss or dispersal of:

a large number of documents during national uprisings and the period of Partitions, especially after the Third Partition of Poland; major losses resulting from military actions in the First World War and a real disaster that happened to documents during the Second World War; [including] collections, from many libraries on the Polish territory and the libraries of centres of Polish life in exile, which were shaped by history. ${ }^{24}$

It was assumed that the NLR should meet certain precise objectives. These were:

setting optimal conditions to collect and maintain a collection of published and hand-written documents which were created throughout the history of Poland and also the ones developed outside Poland which have content or form related to the country; maintaining complex documentation (registration, scientific publication) of these collections; creating an optimal model of information about theses collections; improving and extending the process of their sharing; creating a reproductive basis of Polish source documents. ${ }^{25}$

Apart from the three facilities already mentioned, the activity of the research team was originally supported by: a group of higher education libraries, the Polish Academy of Sciences, centrally located libraries, scientific associations, museums and archives, public libraries with the richest collections and a group of church libraries. ${ }^{26}$ The NLR's activity was intended to be financed from the existing funds from libraries' activity ${ }^{27}$.

The term NLR returned to the public sphere in 1997 when it was used in the Act of 27 June 1997 on the libraries. A year later, pursuant to the Act, the Minister of Art and Culture Regulation of 24 November 1998 on setting the list of libraries whose collections belong to the National Library Resource, defining the structure of the Resource and setting the rules and the scope of its special protection ${ }^{28}$ was published. The document defines the following general rules about the structure of the Resource: it should provide optimal conditions to collect and maintain i) prints and manuscripts by Polish

\footnotetext{
${ }^{22}$ For more about the history, creation and initial programme assumptions of the NLR, see: MARSZALEK, Leon. National Library Resource [Narodowy Zasób Biblioteczny]. In: Library Review [Præeglad Biblioteczny], No. 4, 1978, p. $423-432$.

${ }^{23}$ Ibid., p. 423.

${ }^{24}$ Ibid., p. 426.

${ }^{25}$ Ibid., p. 427-428.

${ }^{26}$ Ibid., p. 430.

${ }^{27}$ Ibid., p. 431.

${ }^{28}$ Minister of Art and Culture Regulation of 24 November 1998 on setting the list of libraries whose collections belong to the National Library Resource, defining the structure of the Resource and setting the rules and the scope of its special protection [Rozporzadzenie Ministra Kultury i S ztuki z. dnia 24 listopada 1998 r. w sprawie ustalenia wykazu bibliotek, których zbiory tworzq narodowy zasób biblioteczny, okéślenia organizacji tego zasobu oraz zasad i zakeresu jego szczególnej ocbrony], Journal of Laws, No. 146, item 955, accessed 7 January 2019, http://prawo.sejm.gov.pl/isap.nsf/DocDetails.xsp?id=WDU19981460955.
} 
authors, ii) polonica ${ }^{29}$ stored in Polish libraries and iii) the documentation of polonica held in foreign collections; it should contain complete documentation of existing resources; and it should provide for the special protection and conservation of library resources. Section 5 of the regulation explains the notion of special protection, including preparation of the protection plan, protection against damage under certain conditions, and the restriction of sharing and recording on other media. A National Library Resource Council, which is referred to below, was also appointed for a four-year term.

An Appendix to the Regulation of 24 November 1998 provides a "list of libraries whose collections belong, in full or in part, to the National Library Resource" which contains the names of 55 institutions. ${ }^{30}$ Almost 11 years later, pursuant to the Minister of Art and Culture Regulation of 27 February 2009 amending the Regulation on setting the list of libraries whose collections belong to the National Library Resource, defining the structure of the Resource and setting the rules and the scope of its special protection, ${ }^{31}$ Elblag Library of Cyprian Norwid was added to the National Library

\footnotetext{
${ }^{29}$ Polonica - a document or item from Poland or Polish-related.

${ }^{30}$ These are: The Central Library of the Polish Association of the Blind in Warsaw, the Gdańsk Library of the Polish Academy of Sciences in Gdańsk, the Main Library of AGH University of Science and Technology in Cracow, the Main Library of Warsaw University of Technology in Warsaw, the Library and Centre for Scientific and Technical Information of Wrocław University of Science and Technology in Wrocław, the Library and Recordings of the Fryderyk Chopin Institute in Warsaw, the Library of the Institute of Literary Research of the Polish Academy of Sciences in Warsaw, the Library of the Institute of Philosophy and Sociology of the Polish Academy of Sciences in Warsaw, the Library of the Institute of Art of the Polish Academy of Sciences in Warsaw, the Jagiellonian Library in Cracow, the Kórnik Library of the Polish Academy of Sciences in Kórnik, the Library of the Castle Museum in Lańcut, the Library of the Museum and Institute of Zoology of the Polish Academy of Sciences in Warsaw, the Library of the Adam Mickiewicz Museum of Literature in Warsaw, the Library of the National Museum in Warsaw and its branches in Krośniewice and Nieborów, the Library of the Tatra Museum in Zakopane, the Library of the Theatre Museum in Warsaw, the National Library in Warsaw, the Library of the Wojciech Kętrzyński Center for Scientific Research in Olsztyn, the Library of the Polish Academy of Sciences in Cracow, the Library of the Poznań Society of Friends of Learning, the Warsaw Public Library in Warsaw, the Raczyński Library in Poznań, the Sejm Library in Warsaw, the Silesian Library in Katowice, the University Library of the John Paul II Catholic University of Lublin in Lublin, the Library of the University of Lódź, the University Library in Poznań, the University of Warsaw Library, the Wrocław University Library, the Library of the Maria Curie Skłodowska University in Lublin, the Library of the Nicolaus Copernicus University in Torun, the Library of the Ossoliński National Institute in Wrocław, the Library of the Jewish Historical Institute in Warsaw, the Library, Museum and Archives of the Stanisław Moniuszko Warsaw Music Society in Warsaw, the Library of the Warsaw School of Economics in Warsaw, the Library of the Stanisław Leszczycki Institute of Geography and Spatial Organization Polish Academy of Sciences in Warsaw, the Library of the Mathematical Institute of the Polish Academy of Sciences in Warsaw, the Central Agricultural Library in Warsaw, the Stefan Szulc Central Statistical Library in Warsaw, the Central Military Library in Warsaw, the Stanisław Konopka Main Medical Library in Warsaw, the Cieszyn Library in Cieszyn, the Stanislaw Staszic Pomeranian Library in Szczecin, the Princes Czartoryski Library - National Museum in Krakow, the Department of Old Prints, Manuscripts and Cartography - National Museum in Krakow, the Zieliński Library of the Płock Scientific Society in Płock, the Nicolaus Copernicus Public Provincial Library in Toruń, the Emanuel Smołka Provincial Public Library in Opole, the Hieronim Lopaciński Provincial Public Library in Lublin, The Joseph Conrad Voivodeship and City Public Library in Gdansk, the Provincial and Municipal Library in Białystok, Provincial Public Library in Kielce, the Cyprian Kamil Norwid Provincial and Municipal Public Library in Zielona Góra and the Provincial and Municipal Public Library in Bydgoszcz.

${ }^{31}$ Minister of Art and Culture Regulation of 27 February 2009 amending the Regulation on setting the list of libraries whose collections belong to the National Library Resource, defining the structure of the Resource and setting the rules and the scope of its special protection [Rozporzadzenie Ministra Kultury i Dziedzictwa Narodowego z. dnia 27 lutego 2009 r. zmieniajacego rozporzadzenie $w$ sprawie ustalenia wykazu bibliotek, których zbiory tworzq Narodowy Zasób Biblioteczny, okeré́lenia organizacji tego zasobu oraz zasad $i$ alkeresu jego sqczególnej ocbrony], Journal of Laws 2009, No. 44, item 356, accessed 7 January 2019, http://dziennikustaw.gov.pl/du/2009/s/44/356.
} 
A. Fluda-Krokos: Protection of the Polish written and printed heritage - National Library Resource

\section{Resource.}

The Minister of Culture and National Heritage Regulation of 4 July 2012 on the National Library Resource $^{32}$ stated that to be included in the NLR, a library resource must satisfy at least one of the following four criteria: historical value, scientific value, cultural value and artistic value. The NLR was divided into seven categories, each of which was subdivided into two price ranges - more or less than the indicated basic amount: drawings (PLN 12,000), engravings (PLN 16,000), photographs (PLN 6,000), manuscripts (PLN 4,000), publications (PLN 6,000), library collections (PLN 16,000) and other library resources (PLN 16,000).

The Regulation introduced an obligation to keep electronic records of the resources that belong to the NLR, which was based on the Minister of Culture and National Heritage Regulation of 29 October 2008 on the way of keeping records of the library resources ${ }^{33}$ and specified the rules for drawing up a plan - to be annually updated - on protecting these electronic resources. It also set the exact dates of executing \ 4.-6 which covered distinguishing resources, dividing them into categories and keeping electronic records, on 31 December 2017.

However, the document, apart from the above-mentioned details, omits the list of 56 facilities whose collections were previously included in the NLR. The list of institutions at the end of the document indicates only two facilities: the Jagiellonian Library in Cracow and the National Library in Warsaw.

Pursuant to the next document - the Minister of Culture and National Heritage Regulation of 16 September 2016 amending the Regulation on the National Library Resource, ${ }^{34}$ five libraries were subsequently added to the NLR, along with the exact date of execution for each of them: Elblag Library of Cyprian Norwid in Elblag (until 31 December 2018), the Scientific Library of the Polish Academy of Arts and Sciences and the Polish Academy of Science in Cracow (until 31 December 2021), the library of the Adam Mickiewicz University in Poznań (until 31 December 2017), the Library of the Ossoliński National Institute in Wrocław (until 31 December 2021) and the Provincial Public Library in Kielce ${ }^{35}$ (until 31 December 2017).

In July 2017, pursuant to the Minister of Culture and National Heritage Regulation of 19 July 2017 amending the Regulation on National Library Resource, ${ }^{36}$ the Silesian Library in Katowice and the Michał Oczapowski Central Agricultural Library in Warsaw were added to the NLR, where the former was to be implemented until 31 December 2020 while the second one until 31 December 2022.

The part of the NLR which does not include monuments is subject to specific provisions concerning the temporary export of its resources beyond Polish borders. These are stated in the Minister of Culture and National Heritage Regulation of 16 August 2017 on the temporary licence to

\footnotetext{
${ }^{32}$ Minister of Culture and National Heritage Regulation of 4 July 2012 on the National Library Resource, [Rozporzadzenie Ministra Kultury i Driedzictwa Narodowego z dnia 4 lipca 2012 r. w sprawie narodowego zasobu bibliotecznego], Journal of Laws 2012, item 797, accessed 7 January 2019, http://prawo.sejm.gov.pl/isap.nsf/DocDetails.xsp?id=WDU20120000797.

${ }^{33}$ Minister of Culture and National Heritage Regulation of 29 October 2008 on the way of keeping records of the library resources.

${ }^{34}$ Minister of Culture and National Heritage Regulation of 16 September 2016 amending Regulation on the National Library Resource, [Rozporzadzenie Ministra Kultury i Džiedzictwa Narodowego z dnia 16 wržeśnia 2016 r. zmieniajacego rozporzadzenie w sprawie narodowego zasobu bibliotecznego], Journal of Laws 2016, item 1548, accessed 7 January 2019, http://prawo.sejm. gov.pl/isap.nsf/DocDetails.xsp?id=WDU20160001548 .

${ }_{35}^{35}$ Each of the mentioned libraries appeared on the list from 1998.

${ }^{36}$ Minister of Culture and National Heritage Regulation of 19 July 2017 amending Regulation on the National Library Resource, [Rozporzadzenie Ministra Kultury i Dziedzictwa Narodowego z. dnia 19 lipca 2017 r. zmieniajacego rozporzadzenie w sprawie narodowego zasobu bibliotecznego] Journal of Laws 2017, item 1439, accessed 7 January 2019, ,http:/ / prawo.sejm.gov.pl/ isap.nsf/DocDetails.xsp?id=WDU20170001439.
} 
export beyond the border library resources that belong to the National Library Resource and are not monuments. ${ }^{37}$ It consists of three appendixes which present sample applications ${ }^{38}$ and explain how to fill them out.

The most recent document applicable to the NLR is the Notice of the Minister of Culture and National Heritage of 3 October 2017 on publication of the consolidated text of the Minister of Culture and National Heritage Regulation on the National Library Resource. ${ }^{39}$ The document consolidates texts of the Regulations of 4 July 2012, 16 September 2016 and 19 July 2018 and the list consists of nine libraries mentioned in the previous texts (two in 2012, five in 2016, two in 2017).

\section{National Library Resource Council}

The Act of 27 June 1997 established a body known as the National Library Resource Council, which is composed of representatives of nine institutions: the National Library (director - chairman), the Jagiellonian Library, the Library of the Ossoliński National Institute, the National Library Council, the Minister of Art and Culture, the Minister of National Education, the Chairman of the State Committee for Scientific Research, the President of the Polish Academy of Sciences and the Main Director of the State Archives. The role of the Council, which acts under rules and regulations, is to assess proposals from libraries that want to join the NLR and the system of information about the NLR, and to prepare and accept programmes of work concerning the NLR. The rules and regulations are included in the Minister of Culture and National Heritage Disposition of 1 March 2012 on the Rules and Regulations of the National Library Resource Council. ${ }^{40}$ This document specifies the frequency of Council meetings, rules for the se-

\footnotetext{
${ }^{37}$ Minister of Culture and National Heritage Regulation of 16 August 2017 on the temporary licence to export beyond the border library resources that belong to the National Library Resource and are not monuments, [Rozporzadzenie Ministra Kultury $i$ Dziedzictwa Narodowego z dnia 16 sierpnia 2017 r. w sprawie pozpoleń na czasowy wywóz za granice materiatów bibliotecznych wchodzacych w sketad narodowego zasobu bibliotecznego i niestanowiacych zabytkóm], Journal of Laws, item 1695, accessed 7 January 2019, ,http://prawo.sejm.gov.pl/isap.nsf/DocDetails.xsp?id=WDU20170001695.

${ }^{38}$ These are as follows: App. 1 - A single licence on temporary export beyond the border of library resources that belong to the National Library Resource and are not monuments within the meaning of section 3.1 of the Act of 23 July 2003 on the protection and care of monuments [Jednorazowe pozwolenie na czasony mywóz za granice materiatu bibliotecznego wchodzacego w sktad Narodowego Zasobu Bibliotecznego i niestanowiacego zabytku w rozumieniu Art. 3 pkt 1 Ustawy z dnia 23 lipca 2003 r. o ochronie zabytków i opiece nad zabytkami], (Journal of Laws 2014, item 1446 as amended); App. 2 - A multiple individual licence on temporary export beyond the border of library resources that belong to the National Library Resource and are not monuments within the meaning of section 3.1 of the Act of 23 July 2003 on the protection and care of monuments [Wielokrotne pozwolenie indywidualne na czasowy wywóz za granice materiatu bibliotecznego wchodzqcego w sklad Narodowego Zasobu Bibliotecznego i niestanowiacego zabytku w rozumieniu Art. 3 pket 1 Ustany z.dnia 23 lipca 2003 r. 0 ochronie zabytkón i opiece nad zabytkami], (Journal of Laws 2014, item 1446 as amended); App. 3 - A multiple general licence on temporary export beyond the border of library resources that belong to the National Library Resource and are not monuments within the meaning of section 3.1 of the Act of 23 July 2003 on the protection and care of monuments [Wielokrotne pozwolenie ogólne na czasowy wywóz za granice materiatón bibliotecznych wchodzacych w sketad Narodowego Zasobu Bibliotecznego i niestanowiacych zabytków w rozumieniu Art. 3 pkt 1 Ustany z dnia 23 lipca 2003 r. o ochronie zabytków i opiece nad zabytkami] (Journal of Laws 2014, item 1446 as amended).

${ }^{39}$ Notice of the Minister of Culture and National Heritage dated 3 October 2017 on publication of the consolidated text of the Minister of Culture and National Heritage Regulation on the National Library Resource [Obwieszczenie Ministra Kultury i Dziedzictwa Narodowego z dnia 3 października 2017 r. w sprawie ogtoszenia jednolitego tekstu rozporzqdzenia Ministra Kultury i Dziedzictwa Narodowego w sprawie narodowego zasobu bibliotecznego], Journal of Laws, item 1948, accessed 7 January 2019, http:/ / prawo.sejm.gov.pl/isap.nsf/DocDetails.xsp?id=WDU20170001948.

${ }^{40}$ Minister of Culture and National Heritage Disposition of 1 March 2012 on the Rules and Regulations of the National Library Resource Council [Zarzqadzenie Ministra Kultury i Driedzictwa Narodowego z dnia 1 marca 2012 r. w sprawie Regulaminu Rady do Spraw Narodowego Zasobu Bibliotecznego], accessed 7 January 2019, http://g.ekspert.infor.pl/p/_dane/akty_pdf/ U26/2012/3/6.pdf\#zoom=90.
} 
lection of the vice-chairman, duties of the chairman, rules governing the invitation of guests, the formation of working parties, the preparation of programmes of work, the creation of minutes and reports, the tasks of the Council and the unpaid character of participation in the Council. It also covers funds, as well as the technical and administrative infrastructure. The first Council was appointed for the 1999-2003 term and was composed of the following members: Michał Jagiełło - Director General of the National Library (Chairman); Teresa Malik - Deputy Director of the Jagiellonian Library (Vice-chairman); Joanna Pasztaleniec-Jarzyńska - Deputy Director of the National Library (Secretary); Dr Dobrosława Platt - Deputy Director of the Ossoliński National Institute; Professor Jan Malicki - Director of the Silesian Library and representative of the National Library Council; Dr Magdalena Slusarska - a representative of the Ministry of Culture; Elżbieta Dudzińska - Director of the Main Library of the Warsaw University of Technology and representative of the Chairman of the State Committee for Scientific Research; Dr Andrzej Ładomirski - Director of the Wrocław University Library until 30 June 2002 and representative of the Ministry of National Education and Sport; Professor Stanisław Sierpowski - Director of the Library of the Polish Academy of Sciences in Kórnik and representative of the Polish Academy of Sciences; Dr Andrzej Biernat - General Director of the Main Directorate for the National Archives and representative of the Main Director of the State Archives. (Professor Jerzy Wisłocki was a member of the Council until September 2001 when he resigned his post in the Council on retirement. $)^{41}$

The Council was not appointed for the years 2004-2006. During its second term, 2007-2011, the following people were appointed to the Council: Dr Tomasz Makowski - Director General of the National Library (Chairman); Dr Andrzej Biernat; Mariusz Dworsatschek - Deputy Director of the Ossoliński National Institute in Wrocław; Professor Jan Malicki; Professor Adam Manikowski - former Director of the National Library; Ewa Potrzebnicka - Deputy Director of the National Library; Professor Zdzisław Pietrzyk - Director of the Jagiellonian Library; Professor Kazimierz Stępień; and Grażyna Anna Piotrowicz. ${ }^{42}$

In the course of the third term, 2012-2016, the Council was represented by: Dr Tomasz Makowski (Chairman); Professor Zdzisław Pietrzyk (Vice-chairman); Dr Mariusz Dworsatschek; Dr Zina Jarmoszuk - Director of the Department of State Patronage, Ministry of Culture and National Heritage; Dr Jan Kozłowski - a Minister's Counsellor in the Department of Strategy, Ministry of Science and Higher Education; Professor Jan Malicki; Beata Pawłowska - Director of the General Education Department, Ministry of National Education; Dr Ewa Perłakowska - Director of the Department of Development of the National Archive Resources, the Main Directorate for National Archives; Ewa Potrzebnicka; Dr Zofia Tylewska-Ostrowska - Director of the Gdańsk Library of the Polish Academy of Sciences. ${ }^{43}$

In its current (2016-2020) term, the Council is represented by: Dr Tomasz Makowski (the chairman); Monika Tłustowska - a Minister's Counsellor in the Department of Manuals, Curriculums and Innovation (pl. Departament Podrecznikón, Programów i Innowacji), Ministry of National Education; Dr Jan Kozłowski - a Minister's Counsellor in the Department of Innovation

\footnotetext{
${ }^{41}$ DĄBROWSKI, Waldemar. The answer to an inquiry on the National Library Resource Council [Odpowiedź na zapytanie w sprawie Rady ds. Narodowego Zasobu Bibliotecznego], accessed 7 January 2019, http://orka2.sejm. gov.pl/IZ4.nsf/main/296C501C.

${ }_{42}$ National Library Report for 2007 [Sprawozdanie Biblioteki Narodowej za rok 2007], accessed 7 January 2019, http:// www.bn.org.pl/download/document/1234173454.pdf, p. 172-173.

${ }^{43}$ National Library Report for 2015 [Sprawozdanie Biblioteki Narodowej za rok 2015], accessed 7 January 2019, http:// www.bn.org.pl/download/document/1465472741.pdf, p. 192.
} 
and Development, the Ministry of Science and Higher Education; Mateusz Adamkowski - Director of the Department of State Patronage, Ministry of Culture and National Heritage; Dr Henryk Niestrój - Deputy of the Main Director of the State Archives; Ewa Potrzebnicka National Library Resource Attorney of the Director General of the National Library, National Library; Professor Zdzisław Pietrzyk; Dr Mariusz Dworsatschek; PhD. Zofia Tylewska-Ostrowska; Professor Jan Malicki - Director of the Silesian Library, National Library Council. ${ }^{44}$

\section{Actual situation}

In 2008 - 10 years after the first Regulation on the NLR was issued - Renata Piejko carried out research on the achievements with regards to the protection of special resources during these 10 years. The results of her survey, published in the magazine "Library", ${ }^{5}$ indicated a number of problems with which libraries deal. Out of 55 surveys sent out, 38 facilities returned them filled in. The survey contained 12 questions, including one open question, about the scope of the institution's collection, methods used for storing and protecting it, and the sharing of resources. The answers indicated that only seven libraries had established NLR commissions, 20 libraries held NLR collections that were specifically secured, and 21 libraries had created a special programme for the protection of their resources. The author concluded that "the National Library Resource [...], requires constant work, efforts and care". ${ }^{46}$

Ewa Stachowska-Musiał, who attempted to sum up 10 years of NLR activity, pointed out ${ }^{47}$ that there was no top-down coordination of activities related to the Resource in Poland, giving the UK and its "National Preservation Office" as an example of best practice. However, the research carried out by the Central Military Library in Warsaw showed that $84.4 \%$ of the investigated libraries ${ }^{48}$ provided information about completing works related to selection of NLR collections. During completion, $78.2 \%$ took historical value as the basic criterion, while $56.2 \%$ developed a plan of protection. Libraries obtained finance for NLR works via their own resources (for as many as $91.2 \%$ of them), from local authorities (for $5.9 \%$ ) and from subsidies (for only $2.9 \%$ ). Respondents highlighted problems with premises, as well as financial and personal $^{49}$ issues as the most common difficulties.

The librarians discussed the NLR issue several times during training and at conferences. We should mention, among other things, a training for directors of libraries whose collections were

\footnotetext{
${ }^{44}$ The council members in the course of 2016-2020 term [Sktad Rady $w$ kadencii 2016-2020], accessed 7 January 2019, http:// www.bn.org,.pl/dla-bibliotekarzy/rada-ds.-narodowego-zasobu-bibliotecznego/sklad-rady-w-kadencji-2016-2020.

${ }^{45}$ PIEJKO, Renata. Narodowy Zasób Biblioteczny - doświadczenia dziesięciu lat. In: Biblioteka, No. 12 (21), 2008 , p. 117-127.

${ }^{46}$ Ibid., p. 126.

${ }^{47}$ STACHOWSKA-MUSIAL Ewa. National Library Resource - experiences of 10 years [Narodowy Zasób Biblioteczny - koncepcja a realizacja]. In: Librarian [Bibliotekary], No. 2, 2008, p. 2-6.

${ }^{48}$ These were: The Central Military Library, Provincial Library in Kielce, the Main Library of Warsaw University of Technology in Warsaw, the Main Library of AGH University of Science and Technology, the Central Agricultural Library, the Central Library of Geography and Environmental Protection, the Library of the Theatre Museum in Warsaw, the Library of the Castle Museum in Lańcut, the Princes Czartoryski Library, the Provincial and Municipal Public Library in Bydgoszcz and the Jagiellonian Library (ibid., p. 6).

${ }^{49}$ Ibid.
} 
part of the NLR (Cracow 2001) ${ }^{50}$ as well as those organised by Marshall Józef Piłsudski of the Central Military Library in Warsaw under the titles Protection of the National Library Resource: Digitalization and ... what next? $(2011)^{51}$ and Protection of the National Library Resource in the times of peace, a crisis and a war (2012)..$^{52}$

In a text published in $2017,{ }^{53}$ Katarzyna Sikora presented a very important aspect of the NLR's definition and protection. She concluded that actual methods of protecting especially library resources will increase probability of destruction of these components of cultural heritage. ${ }^{54}$

The most recent event discussing NLR-related issues was a conference organised by the National Library on 12 October 2017. The subjects of the speeches were related to: NLR history; the storage, protection and creation of the NLR Central Basis, and the application procedure. ${ }^{55}$ Materials from the meeting have not yet been published.

At present, collections from nine libraries are included in the NLR. Their participation in the NLR is presented below.

- National Library (entry pursuant to the Regulation of 2012).

The Statute of the National Library indicates the facility's collections which are included in the NLR: \$14. "The collections that are subject to perpetual archiving belong to the National Library Resource," 56 while $\$ 9$ explains the term of 'perpetual archiving': $\$ 9$. The library perpetually archives only one copy of both Polish library resources and those that concern Poland but were created abroad..$^{57}$

- Jagiellonian Library (entry pursuant to the Regulation of 2012).

Clause 1(2) of the Jagiellonian Library Rules and Regulations states that "part of its collection belongs to the National Library Resource". ${ }^{58}$ Furthermore $\int 9$. defines the resource belonging to the NLR as "The collection of archived copies, which has been in existence since 1969, is subject to perpetual archiving and belongs to the National Library Resource". ${ }^{59}$

A detailed document defining the exact resources included in the NLR is Okólnik no. 2,

\footnotetext{
${ }^{50}$ Post-training materials: SAŁACIŃSKI, Krzysztof (ed.). Protection of the National Library Resource: materials and documents of the training for directors of libraries whose collections in full or in part belong to National Library Resource, Cracow: April 2001 [Ochrona Narodowego Zasobu Bibliotecznego: materialy i dokumenty ze sæloolenia dyrektorów bibliotek, których zbiory w catości lub w czéści tworza Narodowy Zasób Biblioteczny, Kraków, kwiecień 2001 r.], Warsaw: Stowarzyszenie Bibliotekarzy Polskich, 2001. ISBN 8387629758.

${ }^{51}$ Conference proceedings: CZEKAJ-WIŚNIEWSKA, Beata (ed.). Protection of National Library Resource: digitalization and ... what next? [Ochrona narodowego zasobu bibliotecznego: digitalizacja i... co dalej? materialy pokonferencyjne], Warsaw: Centralna Biblioteka Wojskowa im. Marszałka Józefa Piłsudskiego, 2011. ISBN 9788363050047.

${ }^{52}$ Conference proceedings: CZEKAJ-WIŚNIEWSKA, Beata (ed.). Protection of National Library Resource in the time of a peace, a crisis and a war [Ochrona Narodowego Zasobu Bibliotecznego w czasie pokoju, kryzysu i wojny, materialy pokonferencyjne, Warsaw: Centralna Biblioteka Wojskowa im. Marszałka Józefa Piłsudskiego, 2012. ISBN 9788363050092.

${ }^{53}$ SIKORA, Katarzyna. Library Materials, Museum Exhibit, Historic Monuments. A Few Remarks about Legal Definitions and the Law Protection [Materiały biblioteczne a muzealia i zabytki. Kilka uwag o definicjach legalnych i ochronie prawnej]. In: Toruń Bibliological Studies [Toruńskie Studia Bibliologiczne]. No 1 (18), 2017, p. 119-134.

${ }^{54}$ Ibid., p. 132.

${ }^{55}$ Detailed agenda is available on the site: We invite you to the conference "Creating National Library Resource". News - National Library [Zapraszamy na konferencje „Tworzenie Narodowego Zasobu Bibliotecznego”. Aktualności-Biblioteka Narodowa], accessed 7 January 2019, http://www.bn.org.pl/aktualnosci/1410-zapraszamy-na-konferencje-tworzenie-narodowego-zasobu-bibliotecznego.html.

${ }^{56}$ BN Statute - National Library [Statut BN - Biblioteka Narodowa], accessed 7 January 2019, http://www.bn.org. $\mathrm{pl} / \mathrm{o}-\mathrm{bn} /$ statut-bn.

57 Ibid.

${ }^{58}$ Jagiellonian Library Rules and Regulations [Regulamin Biblioteki Jagiellońskie]], p. 3.

${ }^{59}$ Ibid., p. 11.
} 
published by the Director of the Jagiellonian Library on 8 November 2000. According to this document, its NLR collections consist of: the collection of manuscripts (in its entirety); the collection of old prints (in its entirety); the collection of drawings, engravings, bookplates and photographs (in its entirety); the collection of prints from the nineteenth and first half of the twentieth century [up to 1945]: non-serial prints, series, periodicals and leaflets (in its entirety); Polish prints from the years 1945-1968: non-serial prints, series, periodicals, social life documents, company literature, standards and patents (in its entirety); dedicated resources of Polish prints published since 1969: non-serial prints, series, periodicals, social life documents, company literature, standards and patents; dedicated collection of valuable and rare prints "rara"; the dedicated collection of so-called "underground" documents; foreign polonica (Poland-related) documents published post-1945; and the collection of Polish audiovisual and electronic documents created since $1997 .^{60}$

The library has digitized the most valuable and the most damaged of the NLR-included collections as part of the projects "Jagiellonian Digital Library" ${ }^{1}$ and "Digitizing National Resource of the Jagiellonian Library ["Digitalizacja Narodowego Zasobu w Bibliotece Jagiellońskiej"] (stage 1: March-November 2013 - financed by the programme of the Minister of Culture and National Heritage for 2013 entitled "Cultural Heritage, priority 6: Protection and digitization of the cultural heritage"; stage 2: March-November 2015 - financed by the programme of the Minister of Culture and National Heritage for 2015 entitled: "Cultural Heritage, priority: Protection and digitization of the cultural heritage").

The National Library collaborates with the Jagiellonian Library on the "Patrimonium" project, which is co-financed as part of the Operational Programme Digital Poland Objective 2.3 "Digital availability and usefulness of public sector information", Subobjective 2.3.2 "Digital access to cultural resources". The aim of the project is to enable access to digital versions of library resources which are treated as valuable and unique Polish cultural heritage. Digitized and accessible cultural resources will come from the collections of the two biggest Polish libraries: the National Library (NL) and the Jagiellonian Library (JL), whose collections, based on the Act and secondary legislations, are included in the National Library Resource due to their unique value and importance. ${ }^{62}$

- Elblag Library of Cyprian Norwid in Elblag (entry pursuant to the Regulation of 2016).

The information about the part of this library's collections included in the NLR and the number of items therein is published both on the library's website, which records " 9,022 volumes: manuscripts, incunables (among which 14 volumes are the only copies in Poland) and old prints (sixteenth-eighteenth centuries) ${ }^{63}$ and in two documents describing the functioning of

${ }^{60}$ Collections included in the project - Jagiellonian Library [Zbiory objęte projektem - Biblioteka Jagiellonska], accessed 7 January 2019, https://jbc.bj.uj.edu.pl/dlibra/text?id=info-zbiory\&language $=$ en.

${ }^{61}$ Jagiellonian Digital Library [Jagiellońska Biblioteka Cyfrowa], accessed 7 January 2019, https://jbc.bj.uj.edu.pl/dlibra. Digitizing National Resource of the Jagiellonian Library - Jagiellonian Library of the Jagiellonian University [Digitalizacja Narodowego Zasobu w BJ - Biblioteka Jagiellonska Uniwersytetu Jagiellonskiego], accessed 7 January 2019, http://www.bj.uj.edu. $\mathrm{pl}$ /digitalizacja-narodowego-zasobu-w-bj.

${ }_{62}$ About project - National Library [O projekcie - Biblioteka Narodowa], accessed 7 January 2019, http://www.bn.org.pl/ patrimonium/o-projekcie/; Patrimonium - Jagiellonian Library of the Jagiellonian University [Patrimonium - Biblioteka Jagiellońska Uniwersytetu Jagiellońskiego], accessed 7 January 2019, http://www.bj.uj.edu.pl/Patrimonium\#.

${ }^{63}$ Historical collections of the Elblag Library are the most precious in Poland [Zabytkowe zbiory Biblioteki Elblaskiej najcenniejsze w Polsce], accessed 5 January 2019, http://www.bibliotekaelblaska.pl/news/zabytkowe-zbiory-biblioteki-elblaskiej-najcenniejsze-w-polsce.html. 
A. Fluda-Krokos: Protection of the Polish written and printed heritage - National Library Resource

the institution: Rules and regulations of enabling access to the collections of the Elblag library of Cyprian Norwid in Elblag (\$8) ${ }^{64}$ and Organizational rules of the Elblag Library of Cyprian Norwid in Elblag. ${ }^{65}$

Some of these items are accessible on the Elblag Digital Library platform in the collection "Historical resources":

"Historical resources" of the Elblag Library is a very valuable collection of incunables, old prints, manuscripts and mainly German periodicals from the nineteenth and twentieth centuries. A substantial collection of Bibles (around 160 editions in different languages), Pastoral Epistles, songs, Gospels, may be used as an invaluable material for research by theologians. Furthermore, the library owns sixteenth- and seventeenth-century Latin writings of Saint Augustine of Hippo, Saint Thomas Aquinas, Martin Luther, and the letters of the Popes Pius II, Boniface VIII and Leo I, which are used in studies on the history of Church doctrine. A significant part of the collections is philosophical treaties of the classics of thought: Aristotle, René Descartes, Baruch Spinoza, Plato, Seneca the Younger, and the works of Euclid, which are fundamental for the modern geometry. Among the books from the eighteenth century or later, there are mainly German publications concerning theory and history of literature, lexicology, linguistics, literature (German classics, translations of Polish works into German), geography, science and history. The collections of musical documents and cartographic resources are unique in terms of source and cognition. The historic resources amount to 57,000 units. ${ }^{66}$

- Scientific Library of the Polish Academy of Arts and Sciences and the Polish Academy of Science in Cracow (entry pursuant to the Regulation of 2016).

Based on a decision taken at the meeting of the NLR Council on 18 December 2014, drawings, illustrations and bookplates, manuscripts, parchment diplomas, incunables and old prints were included in the Resource.

- The University Library in Poznań (entry pursuant to the Regulation of 2016).

Manuscripts of the medieval codices, which are stored in the Manuscripts Workshop [Pracownia Rękopisów] of the Special Collections Department [Oddział Zbiorów Specjalnych], were entered into the NLR register. ${ }^{67}$ The rules and regulations state that the reading room is the only place where they can used. ${ }^{68}$

- Library of the Ossoliński National Institute in Wrocław (entry pursuant to the Regulation of 2016)

The Library of the Ossoliński National Institute gives information about its collections included in the NLR via its electronic catalogue of resources. ${ }^{69}$ After choosing Collections/provenances [Kolekcje/proweniencje] from the list of search types [Typ wyszukiwania] and entering "naro-

\footnotetext{
${ }^{64}$ Rules and regulations of enabling access to the collections of the Elblag library of Cyprian Norwid in Elblag [Regulamin udostępniania źbiorów Biblioteki Elblaskiej im. Cypriana Norwida w Elblagu], accessed 5 January 2019, http://bip.bibel.pl/ regulaminy/wpis/regulamin-udostepniania-zbiorow.

${ }^{65}$ Organizational rules of the Elblag Library of Cyprian Norwid in Elblag [Regulamin organizacyjny Biblioteki Elblaskiej im. Cypriana Norwida w Elblagu], accessed 5 January 2019, http:/ / bip.bibel.pl/regulaminy/wpis/regulamin-organizacyjny. ${ }^{66}$ Elblag Digital Library - historical resources, [Elblaska Biblioteka Cyfrowa - Zbiory zabytkowe], accessed 5 January 2019, http:/ /dibra.bibliotekaelblaska.pl/dlibra/collectiondescription?dirids=43.

${ }^{67}$ University Library's activity report for 2016 [Sprawozdanie z. działalności Biblioteki Uniwersyteckiej za rok. 2016], accessed 7 January 2019, http:/ /ib.amu.edu.pl/index.php?option $=$ com_content\&task=view\&id $=531 \& I$ temid $=77$, p. 5 .

${ }^{68}$ The University Library in Poznan - rules and regulations of enabling access [Biblioteka Uniwersytecka w Poznaniu - Regulamin udostępniania], accessed 5 January 2019, http:/ / lib.amu.edu.pl/index.php?option=com_content\&task= view\&id=53 1\&Itemid $=77$.

${ }^{69}$ Ossolinski National Institute [Zakład Narodowy im. Ossolinskich], accessed 13 January 2019, http://ossolineum.pl/old/ katalog/.
} 
dowy zasób biblioteczny" in the terms [Terminy] field, the user receives information about the number of resources. On 13 January 2017 there were 8,155 items so described.

- Witold Gombrowicz Provincial Public Library in Kielce (entry pursuant to the Regulation of 2016)

A collection of old prints and books from the nineteenth and early twentieth centuries which form the Kolekcja Sancygniowska [Sancygniów collection] ${ }^{70}$ was included in the NLR.

- $\quad$ Silesian Library in Katowice (entry pursuant to the Regulation of 2017)

The institution enables access to some of its NLR collections through the Silesian Internet Library of Rare Collections, ${ }^{71}$ which is integrated with the Silesian Digital Library. ${ }^{72}$ The platform is supposed to contain ultimately 27,000 publications.

- Michał Oczapowski Central Agricultural Library in Warsaw (entry pursuant to the Regulation of 2017)

The following collections of the library were entered into the NLR register: old prints (items issued from the sixteenth to eighteenth centuries) - 824 volumes; polonica from the nineteenth century (items published between 1801 and 1900); the Warsaw collection, comprising 2,173 volumes of monographs and 681 volumes of periodicals from 96 journal titles; the Puławy collection, comprising 6,291 volumes of monographs and 2,013 vol. of periodicals from 196 journal titles. ${ }^{73}$

\section{Conclusions}

In the year 1998, when the first regulation on the NLR was published, the libraries included in the Resource constituted $0.5 \%$ of all the facilities in Poland $(58 \div 12,500)$, a proportion which had barely changed in $2009-0.5 \%(59 \div 12,577)$. The percentage share had decreased substantially to $0.02 \%(2 \div 10,049)$ by 2012 , when under the new regulation only two facilities were entered onto the NLR list. In 2016, five libraries were added to the NLR, increasing the percentage of libraries included in the Resource to $0.1 \%$ (7 out of 9,567 facilities). At present, the list consists of 10 libraries. However, taking into consideration only a slight decrease in the total number of libraries, no noteworthy percentage increase was observed. We should remember that the list from 1998 included 56 units - exceptional for Polish librarianship, history, culture and science - which constituted around $0.45 \%$ of the much greater number of libraries $(12,500)$.

It is worth noting that at the end of 2017 a special conference dedicated to the NLR was organised. We can only express our hope that new libraries will submit their applications to enter their collections into the NLR, because it is not possible to think about the National Resource without mentioning the Princes Czartoryski Library, the Kórnik Library or provincial

\footnotetext{
${ }^{70}$ More about the collection - see: PIASECKA, Bożena. National Library Resource in the Witold Gombrowicz Provincial Public Library in Kielce [Narodowy Zasób Biblioteczny w Wojewódzkiej Bibliotece Publicznej im. Witolda Gombrowicza w Kielcach]. In: Świętokrayskie Woivodeship - environment, national heritage, regional education [Świętokrayskkie - Środowisko, Dziedzictwo Kulturowe, Edukacja Regionalna], No. 20 (24), 2012, p. 100-104, accessed 7 January 2019 , http://sbc.wbp.kielce.pl/dlibra/docmetadata?id=39199.

${ }^{71}$ Silesian Internet Library of Rare Collections [Ślaska Internetowa Biblioteka Zbiorów Zabytkowych], accessed 8 January 2018 , http://sibzz.bs.katowice.pl/czytaj/91.

72 Silesian Digital Library [Ślaska Biblioteka Cyfrowa], accessed 8 January 2019, https://www.sbc.org.pl/dlibra.

${ }^{73}$ Resources of CBR included in the collections of the National Resource Library [Zbiory CBR zaliczone do Narodowego Zasobu Bibliotecznego], accessed 8 January 2019, https://www.cbr.gov.pl/index.php/aktual/wydarzenia/item/846-zbiory-cbr-zaliczone-do-narodowego-zasobu-bibliotecznego.html?highlight=WyJuYXJvZG93ZWdvIiwiemFzb2J1IiwibmFyb2Rvd2VnbyB6YXNvYnUiXQ==.
} 
and monastery libraries. One good suggestion for the protection of valuable resources is the idea of creating a National Treasures List, which is included in the Act of 10 July 2015 amending the Act on the monument protection and care and the Act on museums, ${ }^{74}$ where section 14a.1 states:

the Heritage Treasures List includes movable historical objects of special value for the cultural heritage, which fall into one of the categories described in the section 64.1 based on the decision issued by the minister competent for culture and national heritage protection, ex officio or on the request of the owner of a movable historical object. ${ }^{75}$

Due to the movable character of library resources, this section may be also apply to them.

\section{References}

CZEKAJ-WIŚNIEWSKA, Beata (ed.). (2011). Protection of the National Library Resource: digitalization and ... what next? Conference proceedings [Ochrona narodowego zasobu bibliotecznego: digitalizacja i... co dalej?: materiaty pokonferencyjne]. Warsaw: Centralna Biblioteka Wojskowa im. Marszałka Józefa Piłsudskiego. ISBN 9788363050047.

CZEKAJ-WIŚNIEWSKA, Beata (ed.). (2012). Protection of the National Library Resource in the time of a peace, crisis and war: Conference proceedings [Ochrona Narodowego Zasobu Bibliotecznego w czasie pokoju, kryzysu i wojny: materialy pokonferencyjne], Warsaw: Centralna Biblioteka Wojskowa im. Marszałka Józefa Piłsudskiego. ISBN 9788363050092.

Culture in 2009 [Kultura w 2009 r.], Warsaw: Główny Urząd Statystyczny, 2010.

Culture in 2012 [Kultura w 2012 r.], Warsaw: Główny Urząd Statystyczny, 2013.

Culture in 2016 [Kultura w 2016 r.], Warsaw: Główny Urząd Statystyczny, 2017.

Culture in 2017 [Kultura w 2017 r.], Warsaw: Główny Urząd Statystyczny, 2018.

Culture in 2018 [Kultura w 2018 r.], Warsaw: Główny Urząd Statystyczny, 2019.

MARSZAŁEK, Leon. National Library Resource [Narodowy Zasób Biblioteczny]. In: Library Review [Przeglad Biblioteczny], No. 4, 1978, p. 423-432.

PIEJKO, Renata. National Library Resource - experiences of 10 years [Narodowy Zasób Biblioteczny - doświadczenia dziesięciu lat]. In: Library [Biblioteka], No. 12(21), 2008, p. 117-127.

SALACIŃSKI, Krzysztof (ed.). (2001) Protection of the National Library Resource: materials and documents of the training for directors of libraries whose collections in full or in part belong to National Library Resource, Cracov, April 2001 [Ochrona Narodowego Zasobu Bibliotecznego: materialy i dokumenty ze szkolenia dyrektorón bibliotek, których zbiory w catości lub w cześsi tworzq Narodowy Zasób Biblioteczny, Kraków, kwiecień 2001 r., Warsaw: Stowarzyszenie Bibliotekarzy Polskich. ISBN 8387629758.

SIKORA, Katarzyna. Library materials, museum exhibit, historical monuments. A few remarks about legal definitions and the law protection [Materiały biblioteczne a muzealia i zabytki. Kilka uwag o definicjach legalnych i ochronie prawnej]. In: Toruń Bibliological Studies [Toruńskie Studia Bibliologiczne], No 1(18), 2017, p. 119-134.

\footnotetext{
${ }_{74}$ Act of 10 July 2015 amending the Act on the monuments protection and care and the Act on museums [Ustawa z dnia 10 lipca 2015 r. o zmianie ustany o ocbronie zabytkón $i$ opiece nad zabytkami oraz ustany o muzeach], Journal of Laws 2016, item 1330, accessed 7 January 2019, http://www.dziennikustaw.gov.pl/ $\mathrm{du} / 2016 / 1330 / 1$.

${ }^{75}$ Ibid., p. 2.
} 
STACHOWSKA-MUSIAL, Ewa. National Library Resource - concept and realisation [Narodowy Zasób Biblioteczny - koncepcja a realizacja]. In: Librarian [Bibliotekarz], No. 2, 2008, p. 2-6.

\section{Internet sources}

About project - National Library [O projekcie - Biblioteka Narodowa], accessed 7 January 2019, http://www.bn.org.pl/patrimonium/o-projekcie/.

Act of 10 July 2015 amending the Act on the monuments protection and care and the Act on museums [Ustawa z. dnia 10 lipca 2015 r. o zmianie ustawy o ochronie zabytków $i$ opiece nad zabytkami oraz ustany o muгeach], Journal of Laws 2016, item 1330, accessed 7 January 2019, http://www.dziennikustaw.gov.pl/du/2016/1330/1.

Act of 27 June 1997 on the libraries [Ustawa z. dnia 27 czerwca 1997 r. o bibliotekach], Journal of Laws 1997, No. 85, item 539, accessed 7 January 2019, http://prawo.sejm.gov.pl/isap.nsf/download.xsp/WDU19970850539/O/D19970539.pdf.

BN Statute - National Library [Statut BN - Biblioteka Narodowa], accessed 7 January 2019, http:/ /www.bn.org.pl/o-bn/statut-bn.

Collections included in the project-Jagiellonian Library [Zbiory objete projektem - Biblioteka Jagiellonska], accessed 7 January 2019, https://jbc.bj.uj.edu.pl/dlibra/text?id=info-zbiory\&language=en.

DAZBROWSKI, Waldemar. The answer for an inquiry on the National Library Resource Council [Odpowiedź na zapytanie w sprawie Rady ds. Narodowego Zasobu Bibliotecznego], accessed 7 January 2019, http:/ / orka2.sejm.gov.pl/IZ4.nsf/main/296C501C.

Digitizing National Resource of the Jagiellonian Library - Jagiellonian Library of the Jagiellonian University [Digitalizacja Narodowego Zasobu w BJ - Biblioteka Jagiellońska Uniwersytetu Jagiellońskiego], accessed 7 January 2019, http://www.bj.uj.edu.pl/digitalizacja-narodowego-zasobu-w-bj.

Elblag Digital Library - historical resources, [Elblaska Biblioteka Cyfrowa - Zbiory zabytkowe], accessed 5 January 2019, http://dlibra.bibliotekaelblaska.pl/dlibra/collectiondescription?dirids=43.

Historical collections of the Elblag Library are the most precious in Poland [Zabytkowe zbiory Biblioteki Elblaskiej najcenniejsze w Polsce], accessed 5 January 2019, http://www.bibliotekaelblaska.pl/ news/zabytkowe-zbiory-biblioteki-elblaskiej-najcenniejsze-w-polsce.html.

Jagiellonian Digital Library [Jagiellonska Biblioteka Cyfrowa], accessed 7 January 2019, https://jbc. bj.uj.edu.pl/dlibra.

Jagiellonian Library Rules and Regulations [Regulamin Biblioteki Jagiellonskie]].

K-03 - library's report [Sprawozdanie bibliotek K-03], accessed 7 January 2019, http:/ / form.stat.gov. $\mathrm{pl}$ /formularze/2018/passive/K-03.pdf.

Library network in Poland, library collections and reading in the nineties [Sieć bibliotek $w$ Polsce, zbiory biblioteczne oraz. czytelnictwo w latach dziewię́dziesiatych], accessed 7 January 2019, http://biurose. sejm.gov.pl/teksty_pdf_01/i-797.pdf.

Minister of Art and Culture Regulation of 24 November 1998 on setting the list of libraries whose collections belong to the National Library Resource, defining the structure of the Resource and setting the rules and the scope of its special protection [Rozporzadzenie Ministra Kultury i Sztuki z. dnia 24 listopada 1998 r. w sprawie ustalenia wykazu bibliotek, których zbiory tworza narodowy zasób biblioteczny, określenia organizacji tego zasobu oraz zasad $i$ zakresu jego szczególnej ochrony], Journal of Laws, No. 146, item 955, accessed 7 January 2019, http://prawo.sejm.gov.pl/isap.nsf/DocDetails.xsp?id=WDU19981460955. 
A. Fluda-Krokos: Protection of the Polish written and printed heritage - National Library Resource

Minister of Art and Culture Regulation of 27 February 2009 amending the Regulation on setting the list of libraries whose collections belong to the National Library Resource, defining the structure of the Resource and setting the rules and the scope of its special protection [Rozporzadzenie Ministra Kultury i Dziedzictwa Narodowego z. dnia 27 lutego 2009 r. zmieniajacego rozporzqdzenie w sprawie ustalenia wykazu bibliotek, których zbiory tworzq narodowy zasób biblioteczny, okerélenia organizacji tego zasobu oraz zasad $i$ zakresu jego szczególnej ochrony], Journal of Laws 2009, No. 44, item 356, accessed 7 January 2019, http://dziennikustaw.gov.pl/du/2009/s/44/356.

Minister of Culture and National Heritage Disposition of 1 march 2012 on the Rules and Regulations of the National Library Resource Council [Zarzqdzenie Ministra Kultury i Dziedzictwa Narodowego z. dnia 1 marca 2012 r. w sprawie Regulaminu Rady do Spraw Narodowego Zasobu Bibliotecznego], accessed 7 January 2019, http://g.ekspert.infor.pl/p/_dane/akty_pdf/U26/2012/3/6.pdf\#zoom=90. Minister of Culture and National Heritage Regulation of 12 December 2017 amending regulation on the method and procedure of including libraries in certain scientific libraries, and setting their list [Rozporzadzenie Ministra Kultury i Dziedzictwa Narodowego z dnia 12 grudnia 2017 r. zmieniajace rozporzadzenie w sprawie sposobu i trybu zaliczania bibliotek do niektórych bibliotek naukowych oraz ustalenia ich wykazu], Journal of Laws 2017, item 2427, accessed 7 January 2019, http://prawo.sejm.gov.pl/isap. nsf/DocDetails.xsp?id=WDU20170002427.

Minister of Culture and National Heritage Regulation of 16 August 2017 on the temporary licence to export beyond the border library resources that belong to the National Library Resource and are not monuments, [Rozporzadzenie Ministra Kultury i Dziedzictwa Narodowego z dnia 16 sierpnia 2017 r. w sprawie pozwoleń na czasony wywóz za granice materiałów bibliotecznych wchodzacych w sktad narodowego zasobu bibliotecznego i niestanowiacych zabytkón], Journal of Laws, item 1695, accessed 7 January 2019, http://prawo.sejm.gov.pl/isap.nsf/DocDetails.xsp?id=WDU20170001695.

Minister of Culture and National Heritage Regulation of 16 September 2016 amending Regulation on the National Library Resource, [Rozporzadzenie Ministra Kultury i Dziedzictwa Narodowego z dnia 16 września 2016 r. zmieniajacego rozporzadzenie w sprawie narodowego zasobu bibliotecznego], Journal of Laws 2016, item 1548, accessed 7 January 2019, http://prawo.sejm.gov.pl/isap.nsf/DocDetails.xsp?id=WDU20160001548 .

Minister of Culture and National Heritage Regulation of 19 July 2017 amending Regulation on the National Library Resource, [Rozporzqdzenie Ministra Kultury i Dziedzictwa Narodowego z. dnia 19 lipca 2017 r. zmieniajacego rozporzqdzenie w sprawie narodowego zasobu bibliotecznego], Journal of Laws 2017, item 1439, accessed 7 January 2019, http://prawo.sejm.gov.pl/isap.nsf/DocDetails. xsp?id=WDU20170001439.

Minister of Culture and National Heritage Regulation of 29 October 2008 on the way of keeping records of the library resources [Rozporzadzenie Ministra Kultury i Dziedzictwa Narodowego z dnia 29 października 2008 r. w sprawie sposobu ewidencji materiatón bibliotecznych], Journal of Laws 2008, No. 205, item 1238, accessed 2 January 2019, http://prawo.sejm.gov.pl/isap.nsf/DocDetails. xsp?id=WDU20082051283.

Minister of Culture and National Heritage Regulation of 4 July 2012 on the National Library Resource, [Rozporzadzenie Ministra Kultury i Dziedzictwa Narodowego z dnia 4 lipca 2012 r. w sprawie narodowego zasobu bibliotecznego], Journal of Laws 2012, item 797, accessed 7 January 2019, http:/ / prawo.sejm.gov.pl/isap.nsf/DocDetails.xsp?id=WDU20120000797. 
Minister of National Education and Sport Regulation of 29 April 2003 on the framework statute of the public pedagogical library [Rozporzqdzenie Ministra Edukacji Narodowej i Sportu z dnia 29 kwietnia 2003 r. w sprawie ramowego statutu publicznej biblioteki pedagogicznej], Journal of Laws 2003, No. 89, item 825, accessed 7 January 2019, http://prawo.sejm.gov.pl/isap.nsf/DocDetails. xsp?id=WDU20030890825.

Minister of National Education Regulation of 28 February 2013 on the detailed rules of functioning of the public pedagogical libraries [Rozporzadzenie Ministra Edukacji Narodowej z. dnia 28 lutego 2013 r. w sprawie szczegótowych zasad działania publicznych bibliotek pedagogicznych], Journal of Laws 2013, item 369, accessed 7 January 2019, http://prawo.sejm.gov.pl/isap.nsf/DocDetails. xsp?id=WDU20130000369.

National Library Report for 2007 [Sprawozdanie Biblioteki Narodowej za rok 2007], accessed 7 January 2019, http:/ /www.bn.org.pl/download/document/1234173454.pdf.

National Library Report for 2015 [Sprawozdanie Biblioteki Narodowej za rok 2015], accessed 7 January 2019, http://www.bn.org.pl/download/document/1465472741.pdf.

Notice of the Minister of Culture and National Heritage of 3 October 2017 on publication of the consolidated text of the Minister of Culture and National Heritage Regulation on the National Library Resource [Obwieszczenie Ministra Kultury i Dziedzictwa Narodowego z dnia 3 października 2017 r. w sprawie ogtoszenia jednolitego tekstu rozporzqdzenia Ministra Kultury i Dziedzictwa Narodowego w sprawie narodowego zasobu bibliotecznego], Journal of Laws, item 1948, accessed 7 January 2019, http://prawo.sejm.gov.pl/isap.nsf/DocDetails.xsp?id=WDU20170001948.

Organizational rules of the Elblag Library of Cyprian Norwid in Elblag [Regulamin organizacyjny Biblioteki Elblaskiej im. Cypriana Norwida w Elblagu], accessed 5 January 2019, http://bip.bibel.pl/ regulaminy/wpis/regulamin-organizacyjny.

Ossolinski National Institute [Zakład Narodowy im. Ossolinskich], accessed 13 January 2019, http:// ossolineum.pl/old/katalog/.

Patrimonium - Jagiellonian Library of the Jagiellonian University [Patrimonium - Biblioteka Jagiellonska Uniwersytetu Jagiellonskiego], accessed 7 January 2019, http://www.bj.uj.edu.pl/Patrimonium\#.

PIASECKA, Bożena. National Library Resource in the Witold Gombrowicz Provincial Public Library in Kielce [Narodowy Zasób Biblioteczny w Wojewódzkiej Bibliotece Publicznej im. Witolda Gombrowicza w Kielcach]. In: Świętokrayskie Woivodeship - environment, national heritage, regional education [Świętokrazyskie - Środowisko, Dziedzictwo Kulturowe, Edukacja Regionalna], No. 20 (24), 2012, p. 100-104, accessed 7 January 2019, http://sbc.wbp.kielce. $\mathrm{pl} /$ dlibra/docmetadata?id $=39199$.

Resources of CBR included in the collections of the National Resource Library [Zbiory CBR zaliczone do Narodowego Zasobu Bibliotec₹nego], accessed 8 January 2019, https://www.cbr.gov.pl/index.php/ aktual/wydarzenia/item/846-zbiory-cbr-zaliczone-do-narodowego-zasobu-bibliotecznego. html?highlight=WyJuYXJvZG93ZWdvIiwiemFzb2J1IiwibmFyb2Rvd2VnbyB6YXNvY$\mathrm{nUiXQ}==$.

Rules and regulations of enabling access to the collections of the Elblag library of Cyprian Norwid in Elblag [Regulamin udostęnniania zbiorów Biblioteki Elblaskiej im. Cypriana Norwida w Elblagu], accessed 5 January 2019, http://bip.bibel.pl/regulaminy/wpis/regulamin-udostepniania-zbiorow.

Silesian Digital Library [Ślaska Biblioteka Cyfrowa], accessed 8 January 2019, https://www.sbc.org. $\mathrm{pl} /$ dlibra. 
A. Fluda-Krokos: Protection of the Polish written and printed heritage - National Library Resource

Silesian Internet Library of Rare Collections [Ślaska Internetowa Biblioteka Zbiorów Zabytkowych], accessed 8 January 2018, http://sibzz.bs.katowice.pl/czytaj/91.

The Act of 25 October 1991 on organizing and running cultural activity [Ustawa z. dnia 25 października 1991 r. o organizowaniu i prowadzeniu działalności kulturalnej], Journal of Laws 1991, No. 114, item 493, accessed 7 January 2019, http://prawo.sejm.gov.pl/isap.nsf/DocDetails. xsp?id=wdu19911140493.

The council members in the course of 2016-2020 term [Sklad Rady w kadencji 2016-2020], accessed 7 January 2019, http://www.bn.org,.pl/dla-bibliotekarzy/rada-ds.-narodowego-zasobu-bibliotecznego/sklad-rady-w-kadencji-2016-2020.

The University Library in Poznan - rules and regulations of enabling access [Biblioteka Uniwersytecka $w$ Poznaniu - Regulamin udostęniania], accessed 5 January 2019, http://lib.amu.edu.pl/index. php?option $=$ com_content\&task $=$ view\&id $=531 \&$ Itemid $=77$.

University Library's activity report for 2016 [Sprawozdanie z działalności Biblioteki Uniwersyteckiej za rok. 2016], accessed 7 January 2019, http://lib.amu.edu.pl/index.php?option=com_content\&ta sk $=$ view\&id $=531 \&$ Itemid $=77$, p. 5 .

We invite you to the conference "Creating National Library Resource". News - National Library [Zapraszamy na konferencje „Tworzenie Narodowego Zasobu Bibliotecznego”. Aktualności-Biblioteka Narodowa], accessed 7 January 2019, http://www.bn.org.pl/aktualnosci/1410-zapraszamy-na-konferencje-tworzenie-narodowego-zasobu-bibliotecznego.html. 